\title{
A Study on the Influence of Instagram on Business Development of Unorganised Netpreneurs Among Various Popular Social Media Platforms
}

\author{
Sibichan Thomas $^{1 *}$, S. Rajendran ${ }^{2}$ \\ ${ }^{I}$ M.Phil. Scholar, Department of Commerce, Prist Deemed to be University, Thanjavur, India \\ ${ }^{2}$ Professor \& Head, Department of Commerce, Prist Deemed to be University, Thanjavur, India \\ *Corresponding author: pkpristuni@gmail.com
}

\begin{abstract}
Social networking sites have become a new tool in marketing. A large number of companies already use Instagram as a platform for marketing. Myriads of opportunities are waiting for retailers through social media networks. Instagram based platform provides retailers a new arena. Most of the netpreneurs are using Instagram for customer relations, and to introduce new brands to the customers. It has also been proved as one of the cost effective marketing method for retailers. Throughout the study and survey, it has been proved that about $90 \%$ of respondents agree that Instagram is one among the top social sites, that supports marketing. Most of the netpreneurs use different tactics in business, by putting offers and promotion. Instagram could be used as a better platform for the collaboration of different netpreneurs to handle the tasks. Though social media marketing is time consuming, by outsourcing netpreneurs can overcome the main hurdle in this marketing strategy.
\end{abstract}

Keywords: Business promotion, Communication, Netpreneurs, Online Marketing, Social network.

\section{Introduction}

In the technically developed modern world, social networking marketing is growing at warp speed. With the increasing number of people joining social media sites and spending their time on social networking sites, social media industry is booming like never before. With the increasing number of consumers hanging around the popular social networks, every business today needs to use social media channels as an important tool for marketing.

Among all social networking sites, Instagram has become an important tool for marketing. At present, a large number of companies are using Instagram to create interactions between businessman and consumers. Social media sites are used by a verity of consumers, and thus, it can provide shopping services even for retailers. The retailers can introduce their products and promise their brand to the consumers, using social network as a platform.

This report and detailed study is mainly concentrating on the importance of Instagram and different business branches, but specified on marketing area. There have been different researches and experiments on social media marketing, but developed researches in the area of retailers and their benefits through social network sites are limited. This study tries to analysis of the achievements; retailers can gain through the use of social media marketing, specifically concentrating on Instagram.

The purpose of this report is to analyze the influence of instagram on business development of unorganized netpreneurs among various popular social media platform.

\section{Objectives of the Study}

- To identify the influence of Instagram on business development for unorganized netpreneurs.

- To determine the impact of Instagram on business performance and growth.

- To research the importance of social media marketing for today's business.

- To explore the possibilities Instagram marketing.

\section{Scope of the Study}

The scope of this study aims at the influence of Instagram on business development of unorganized netpreneurs. 100 Instagram based entrepreneurs polled their input/opinion on a google form survey with fine-tuned set of questionnaire. The responses were processed both graphically and systematically using tools like percentage analysis and chi-square analysis in order to make a well structured final form of result.

\section{Methodology}

Research Design:

Partly descriptive and partly analytical design is used in this study to describe the state of affairs of individual and approach towards the specific research. 
Sample Size:

For this study, I have taken a sample size of 100 numbers.

Sampling Technique:

In this study, I have used convenient sampling technique.

Source of data:

The main source of the data used in this report is collected from a number of questionnaires and the supporting data for this study is prepared by using reference books, internets, broachers and company profiles.

\section{A. Tools for analysis of data}

Percentage analyses: This analysis facilitates comparison and is helpful in evaluating the relative change in item.

Percentage $(\%)=($ Number of Respondents/Total Number of Respondents) x 100

\section{Scope of Instagram Marketing}

Instagram is a social sharing media developed in 2010 mainly for smart phones. From the very beginning, Instagram is much popular among a large number of people.

Marketing through Instagram provides a better platform for the manufacturer to introduce the products to the consumers and to advertise new brands with new offers and can be used to a major platform to converse with the customer. Instagram could also be used to collect customer's various reactions and opinions and to know the preference of the customers.

Table 1

Core product or services of the business

\begin{tabular}{|c|c|c|}
\hline Product & No. of Respondents & Percentage \\
\hline Craft item & 27 & 27 \\
\hline Garments & 25 & 25 \\
\hline Food items & 21 & 21 \\
\hline Cosmetics & 5 & 5 \\
\hline Others & 22 & 22 \\
\hline Total & $\mathbf{1 0 0}$ & $\mathbf{1 0 0}$ \\
\hline
\end{tabular}

Out of the total number, 27 percent are dealing with handmade craft business, 25 percent are dealing with garment business, 21 percent are dealing with food items, 5 percent deal with cosmetics business and 22 percent doing other business than the above all. From the above interpretation it has been concluded that, most of the respondents are dealing with craft items and food items and least are dealing with cosmetic business.

Table 2

Source of initial idea for the business

\begin{tabular}{|c|c|c|}
\hline Response & No. of respondents & Percentage \\
\hline Social Media & 38 & 38 \\
\hline Friends \& Family & 31 & 31 \\
\hline Self & 31 & 31 \\
\hline Total & $\mathbf{1 0 0}$ & $\mathbf{1 0 0}$ \\
\hline
\end{tabular}

38 percent netpreneurs got the idea of their business through social media, 31 percent got idea through friends and family and rest 31 percent got idea from themselves.

Table 3

Instagram's benefits on business

\begin{tabular}{|l|c|c|}
\hline \multicolumn{1}{|c|}{ Response } & $\begin{array}{c}\text { No. of } \\
\text { respondents }\end{array}$ & Percentage \\
\hline Cost effective way of marketing & 29 & 29 \\
\hline Good for business promotion & 26 & 26 \\
\hline $\begin{array}{l}\text { Good for building relationship with } \\
\text { customers }\end{array}$ & 45 & 45 \\
\hline Total & $\mathbf{1 0 0}$ & $\mathbf{1 0 0}$ \\
\hline
\end{tabular}

Out of 100 respondents, 45percent of them said Instagram is good for building relationship with customer, 29 percent of them said Cost effective way of marketing, while 26 percent of them said its good for promotion. So its concluded that Most of the netpreneurs are considering Instagram to build relation with customers.

Table 4

Source of insight towards current market and key players

\begin{tabular}{|c|c|c|}
\hline Response & No. of Respondents & Percentage \\
\hline Social media & 70 & 70 \\
\hline Manual research & 22 & 22 \\
\hline Professional & 8 & 8 \\
\hline Total & $\mathbf{1 0 0}$ & $\mathbf{1 0 0}$ \\
\hline
\end{tabular}

The table reveals that out of 100 respondents, 70 percent of them stated social media is the tool to study the market and figure out the key players, 22 percent of them depending on Manuel research while 8 percent are outsource the subject to professionals. So it is concluded that most of the netpreneurs are considering social media to study the market and find out its key players.

Table 5

Modes of product delivery

\begin{tabular}{|c|c|c|}
\hline Response & No. of Respondents & Percentage \\
\hline Postal Service & 24 & 24 \\
\hline Courier Service & 44 & 44 \\
\hline In person & 32 & 32 \\
\hline Total & $\mathbf{1 0 0}$ & $\mathbf{1 0 0}$ \\
\hline
\end{tabular}

Table explains that 24 percent out of 100 percent uses Postal service, the majority 44 percent uses courier service and 32 percent directly deliver the products to customers (hand by hand). We can it conclude that, most of the respondents use courier services to deliver their products.

Table 6

Key person for the business operation

\begin{tabular}{|c|c|c|}
\hline Response & No. of Respondent & Percentage \\
\hline Own & 84 & 84 \\
\hline Assistant & 12 & 12 \\
\hline Professionals & 4 & 4 \\
\hline Total & $\mathbf{1 0 0}$ & $\mathbf{1 0 0}$ \\
\hline
\end{tabular}

It reveals that out of 100 respondents 84 percent setup and maintain their business account, 12 percent appointed an assistant to manage their business account and remaining 4 
percent appointed a professional for set up and manage their business account.

Table 7

Modes to expand the business

\begin{tabular}{|l|c|c|}
\hline \multicolumn{1}{|c|}{ Response } & No. of respondents & Percentage \\
\hline Introduction & 44 & 44 \\
\hline Tie up with other business & 15 & 15 \\
\hline Retail business & 21 & 21 \\
\hline Total & 80 & 80 \\
\hline Not willing to expand & 20 & 20 \\
\hline Total & $\mathbf{1 0 0}$ & $\mathbf{1 0 0}$ \\
\hline
\end{tabular}

Out of 100 numbers form above questions 80 percent respondents are planning to expand their business. Out of this 80 percent, 55 percent of the respondents are introducing new products in order to expand their business, 18.75 percent are trying to tie up with other netpreneurs, 26.25 percent are trying retail business while 20 percent are not willing to expand their business. So it is concluded that most of the netpreneurs are introducing products to expand their business.

Table 8

Disadvantages of Instagram on business

\begin{tabular}{|l|c|c|}
\hline \multicolumn{1}{|c|}{ Response } & $\begin{array}{c}\text { No. of } \\
\text { respondents }\end{array}$ & Percentage \\
\hline Time consumption & 49 & 49 \\
\hline Users are allowed to post negative content & 32 & 32 \\
\hline Variation in profit margin & 19 & 19 \\
\hline Total & $\mathbf{1 0 0}$ & $\mathbf{1 0 0}$ \\
\hline
\end{tabular}

49 percent of them said Instagram is time consuming is the main disadvantage, 32 percent pointed the ability to users to post negative comments as disadvantage, while 19 percent said profit margin variation is the main disadvantage. So it is concluded that Time consuming factor is the main disadvantage of Instagram in business.

\section{Findings}

1. Most of the netpreneurs have chosen random core products. There is no inclination of the trend towards any particular product. This prove that, Instagram based platforms are suitable for any kind of business regardless of its products/service.

2. The inspiration to setup Instagram based business are through random sources like social media, friends and others etc.

3. Almost all the netpreneurs are using Instagram in marketing area of the business, especially for customer relations, Promotions and finally for a cost effective marketing strategy.

4. Large number of netpreneurs are considering social media to study the market.

5. Most of the respondents chose courier service to reach the products out to its customers.

6. Around $84 \%$ of the respondents are running their business on their own, without depending on others.

7. Over $80 \%$ of the respondents are planning to expand their business.
8. As multiple opinions are available, Respondents are having different plans to expand their business.

9. Most of the respondents stated Instagram is too time consuming. This is the main disadvantage of Instagram over outlet business.

\section{Suggestions}

- Instagram and other social media platforms are well used by many netpreneurs. This demands a new innovative product/service that provides better efficient solutions that expands Instagram and other social media platforms. There is no such product/service available on current market. So as an IT company, it would be better If as designs can come up with these kinds of products.

- Most of the netpreneurs are getting their initial motivation from social media to start up a business; so for a digital marketing company, it would be a great opportunity to get wide range of marketing options by connecting netpreneurs with various products which needs marketing.

- Netpreneurns are marketing the business by putting offers and promotions. It would be better if we are able to collaborate with as many netpreneurs as possible by handling these marketing tasks.

- Most of the netpreneurs are willing to expand their business. For an IT company it's a great opportunity to do the business by means of setting up online market, where they can attract netpreneurs by means of market platforms.

Netpreneurs have widely accepted the fact that marketing on Instagram is time consuming. So there will be great tendency to outsource this task, if they are with better and effective solution providers. This is a great opportunity for any digital marketing firm.

\section{Conclusion}

Social media networking has become a new platform for business development. A large number of netpreneurs widely use social media to expand their business. Among all social networking sites, Instagram has achieved a providing role as an important marketing tool. About $70 \%$ companies are using Instagram to their advantage. Even though this topic is well researched, there have been no specific studies, how retailer's benefits from social networking sites, especially by Instagram. More experiments of business opportunities in their stream are yet to be done. Many retailers have accessed social media, but still there needs more development in this stream. There are a large number of netpreneurs, who are willing to expand their business, but there are a large number of limitations in front of them as social media is time consuming. But by outsourcing this task, netpreneurs achieve profitable developments in their business. 


\section{References}

[1] Ratna Sinah, "The impact of Social media on business growth and performance in India," International journal of research in management and business studies, 2017.

[2] Bashar Abu, Ahmad Irshad, and Wasiq, Mohammad, "Effectiveness of social media as a marketing tool: An empirical study," International
Journal of Marketing, Financial Services \& Management Research, vol. $1,2012$.

[3] Handley Ann, "Everybody writes", Create Space Independent publishing platform, 2017.

[4] Hall John "Top of Mind”, McGraw Hill Professional, 2017.

[5] www.digitalcommons.edu.com

[6] www.manegementstudyguide.com

[7] www.business2community.com 